NBER WORKING PAPER SERIES

\title{
FIXED EXCHANGE RATES, INFLATION AND MACROECONOMIC DISCIPLINE
}

Sebastian Edwards

Fernando J. Losada

Working Paper No. 4661

\section{NATIONAL BUREAU OF ECONOMIC RESEARCH 1050 Massachusetts Avenue \\ Cambridge, MA 02138 \\ February 1994}

This paper is part of NBER's research program in International Finance and Macroeconomics. Any opinions expressed are those of the authors and not those of the National Bureau of Economic Research. 
NBER Working Paper \#4661

February 1994

\title{
FIXED EXCHANGE RATES, INFLATION \\ AND MACROECONOMIC DISCIPLINE
}

\begin{abstract}
We use data from Guatemala and Honduras to investigate some implications of the Purchasing Power Parity theory over the long run. In particular, we address two questions. First, to what extent did the fixed exchange rate regime impose macroeconomic discipline on these countries. Second, what was the impact of terms of trade shocks and growth differentials on inflation rate differentials between those countries and the United States. We found that the fixed parities regime worked properly until the mid-1970s, providing some constraint on central bank behavior. However, the evidence suggests that the fixed exchange rate system was not sufficient to avoid inflation outbursts and balance of payments crises. Specifically, it was unable to accommodate large negative terms of trade shocks in the late 1970s and early 1980s.
\end{abstract}

Sebastian Edwards

Room I-8005

The World Bank

1818 H Street, NW

Washington, D.C. 20433

and NBER
Fernando J. Losada

Room I-8178

The World Bank

1818 H Street, NW

Washington, D.C. 20433 


\section{Introduction}

Gustav Cassel's formulation of the purchasing power parity (PPP) doctrine in 1916 was followed by decades of controversy.' This debate became particularly heated in the 1950s and early 1960s, when a number of analysts used PPP calculations to evaluate whether specific currencies were overvalued or undervalued (Houthakker, 1962). By explicitly introducing nontradable goods and technological progress into the analysis, Bela Balassa's (1964) reinterpretation of PPP helped place things in perspective. He convincingly argued that in the presence of differentials in technological progress across counties and sectors, PPP computations would tend to differ systematically from the equilibrium (real) exchange rate. Balassa showed that under a plausible set of assumptions - namely that technological progress is faster in tradables than in nontradables, and that technological progress is the main source of growth -, the rate of inflation in the faster growing country would be, in equilibrium, higher than that of the slower grower. ${ }^{2}$ This interpretation of inflation differentials continues to be popular among international economists. For instance, Marston (1987) has relied on it to explain Japan's real exchange rate behavior vis-a-vis the U.S., and Svensson (1993) has mentioned it as a possible explanation for the collapse of the European Exchange Rate Mechanism in 1993.

Many recent policy analyses of open economies have been strongly influenced by Balassa's broad work on exchange rates and economic reform. For instance, much of the work on the effect of terms of trade shocks on real exchange rate behavior has built on Balassa's contributions in the 1960s. ${ }^{3}$ Also, discussions on the merits of altemative exchange rate regimes in developing and Eastern European countries have been influenced by Balassa's work on policy reform. This has been particularly the case in policy debates on the desirability of using fixed nominal exchange rates as 
anchors in stabilization programs (see Balassa 1987 and 1989; see also Corden 1991 and Edwards 1993).

In this paper we use data from two Central American countries - Guatemala and Honduras - to investigate some PPP-related issues close to Balassa's early work. These two nations had fixed exchange rate regimes for nearly seven decades, and provide a unique opportunity for testing some of the most important implications of PPP over the (very) long run. The Honduran currency was uninterruptedly pegged to the dollar between 1918 and 1990; Guatemala's currency was fired to the dollar between 1926 and 1986 (see the Appendix for details). We are particularly interested in addressing two questions: first, to what extent the reliance on fixed exchange rates for such a long period imposed macroeconomic discipline to these countries. That is, to what extent inflation in these countries was determined by "world" inflation. We deal with this issue primarily from the point of view of modern credibility theories that emphasized the role of institutional constraints as an effective way of tieing the hands of opportunistic governments. Second, we investigate the way in which terms of trade changes and growth differentials affected inflation rates differentials between each of these countries and the United States. We found that in both countries the fixed exchange regime worked relatively well until the mid-1970s. In fact, the evidence provides some support to the view that fixed exchange rates acted for long periods of time as a constraint on Central Bank behavior. However, the analysis also shows that the mere existence of a fixed exchange rate was not a sufficient condition for avoiding inflation outbursts and balance of payments crises. More specifically, the evidence suggests that having maintained a fixed exchange rate during a period of large negative terms of trade shocks in the late 1970s and early 1980s may have had negative effects on these countries. 
The paper is organized as follows. Section II deals with PPP tests. We first use annual data for $1930-1983$ to perform standard tests of the relative version of PPP holds in Guatemala and Honduras. We then use modern time series techniques on quarterly data for 1957-1983 to further investigate this issue. We find that when these more powerful tests are applied it is possible to reject the relative version of PPP for both Central American nations. Section III tries to account for the factors affecting departures from PPP. In particular, we consider the potential roles of both monetary and real factors. We test whether these countries exercised independent monetary and/or credit policies during this period. Regarding real shocks, we investigate whether terms of trade disturbances and growth differentials affected inflation rate differentials. Section IV deals with these countries' exchange rate crises during the late 1980s and early 1990s. We argue that after the oil shocks and the debt crisis both of these countries experienced significant changes in their credit and fiscal policies. The appendix provides a brief history of Guatemala and Honduras' experiences with fixed exchange rates.

\section{Fixed Exchange Rates and PPP in Central America: A Long Run Empirical Perspective}

Even though Honduras had a fixed exchange rate from 1918 to 1990 and Guatemala between 1926 and 1986, we have only been able to find macroeconomic data for both countries from the 1930s. Figure 1 displays annual rates of inflation for 1930-1992 for Guatemala, Honduras and the U.S." This figure suggests that it is possible to distinguish three broad subperiods. The first goes from 1930 to approximately 1955 and is characterized by rates of inflation in the two Central American countries that are both higher and more volatile than those in the U.S. This 


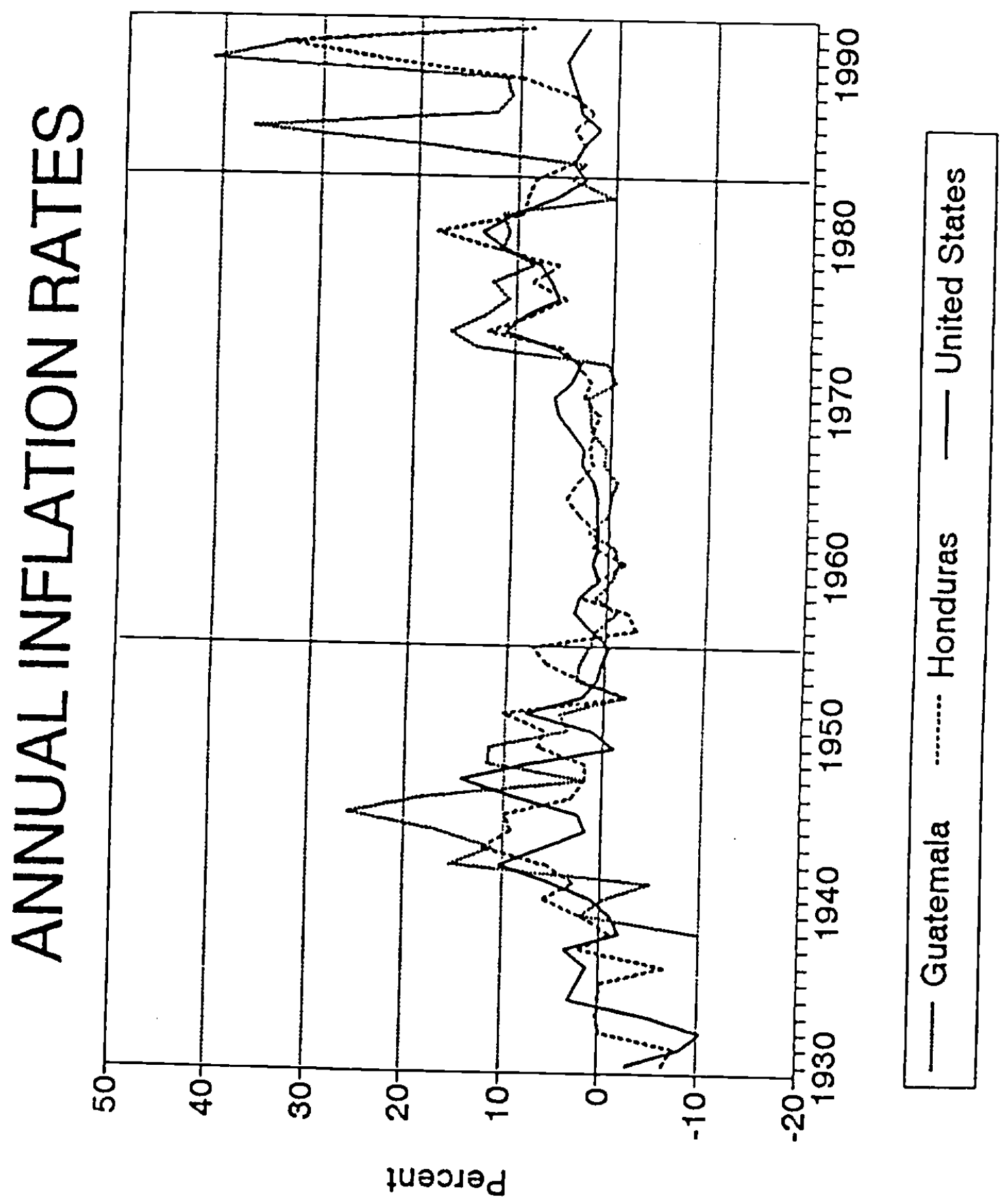


subperiod was characterized by dramatic economic turbulence, including the Great Depression, the Second World War, and the Korean War. The second subperiod goes from approximately 1956 to 1983 , and is characterized by low and relatively stable rates of inflation. As can be seen from Table 1, during this era the average rate of inflation was lower in both Central American countries than in the U.S. Interestingly enough, this period was not free of external disturbances, as the world endured two major oil shocks and in 1982 the eruption of the debt crisis. Finally, the third period goes from 1984 through 1992 and is characterized by the development of major imbalances that ended, in both Guatemala (1986) and Honduras (1990), with the abandonment of the fixed exchange rate regime. An important characteristic of this subperiod is that the authorities in both countries responded to the debt crisis by following a domestic credit policy that was clearly at odds with the countries' history, and that eventually proved to be inconsistent with maintaining a pegged exchange rate.

In this section we use both yearly and quarterly data to test whether inflation in our two Central American countries deviated significantly from that of the U.S.. We first estimate traditional partial adjustment-type equations on annual data. We then use time series techniques on quarterly data to gain further insights on the behavior of inflation differentials.

\section{U.1 Testing for the Relative Version of PPP Using Annual Data}

In its simplest form, what Balassa (1964) called the relative version of PPP, states that under fixed exchange rates inflation rates across countries will not differ significantly. However, as pointed out by Balassa (1964) and previously by Cassel (1916), in the short run it is still possible for domestic inflation to deviate from "world" inflation. The simplest way to incorporate the idea that in the long run the 


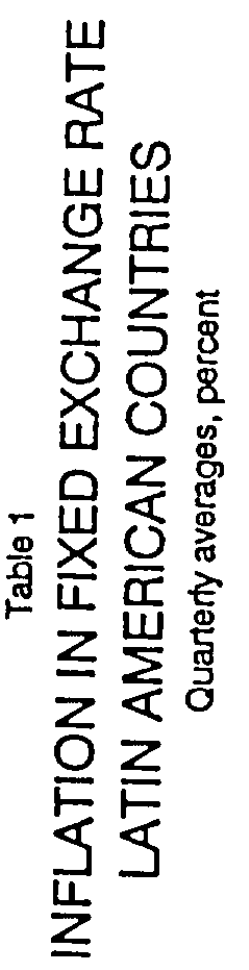

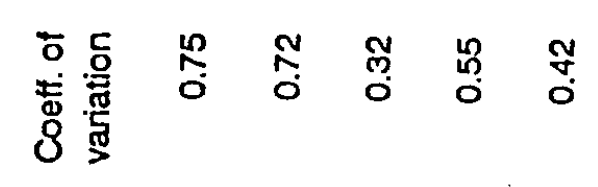

耐

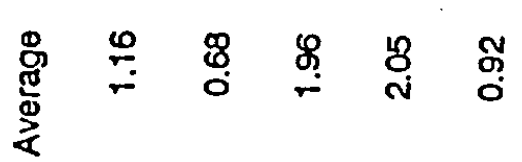

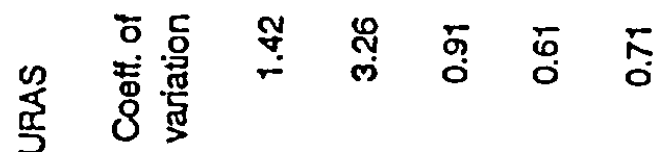

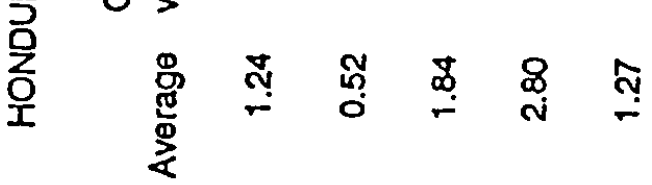

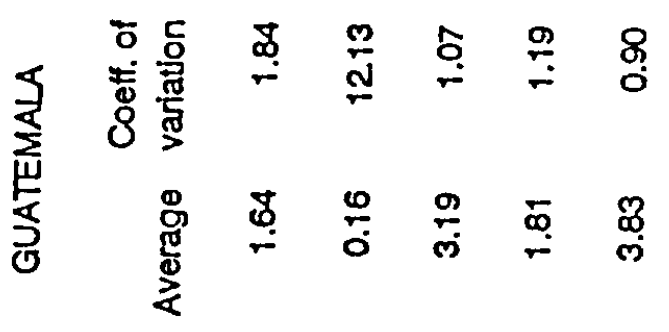

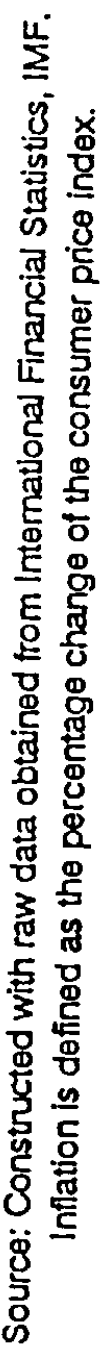


relative version of PPP holds is by postulating a partial adjustment equation of the following type (Frenkel, 1978):

$$
\operatorname{Inf}(t)=a_{0}+a_{1} \operatorname{InfUS}(t)+a_{2} \operatorname{Inf}(t-1)+u(t)
$$

where $\operatorname{In} f(t)$ is inflation in the country in question in period $t$, InfUS is foreign inflation, which in our case is inflation in the US, and $u(t)$ is an error term assumed to have the usual properties.' If PPP holds in the long run, $a_{1} /\left(1-a_{2}\right)$ should not be significantly different from one. Naturally, in this formulation coefficient $a_{2}$ measures the speed at which deviations from PPP are eliminated.

Table 2 presents the results obtained from the estimation of equation (1) using annual data from Guatemala and Honduras for two subperiods: 1930 (or the first year for which there are data) and 1982, and 1956 through 1982. As can be seen from Table 2, the relative version of PPP is rejected for the period that goes from the 1930s to 1983. The Chi-square statistic for testing whether the long-run coefficient of U.S. inflation is unity is 4.9 for Guatemala and 5.4 for Honduras. However, it is not possible to reject it, in either country, for the more tranquil period 1957-83: In this case the long run coefficient of U.S. inflation is not significantly different from one (the Chi-square statistic is 1.9 for Guatemala and 0.18 for Honduras).

Traditional tests of PPP of the type reported above are subject to some limitations, including the use of annual data and the assumption that inflation rates are stationary. Additionally, the test on coefficient restrictions used to investigate whether the coefficient of InfUS is unity in the long run has a relative low power. As a way to deal with these issues we have used quarterly data for 1957-83 to further investigate the behavior of inflation rates under fixed parities in these countries. 
TABLE 2

\section{LONG RUN RELATIVE VERSION OF PPP (a)}

(t-statistics in parentheses)

\begin{tabular}{lrrrr} 
& \multicolumn{2}{c}{ GUATEMALA } & \multicolumn{2}{c}{ HONDURAS } \\
PERIOD & $1939-83$ & $1957-83$ & $1931-83$ & $1957-83$ \\
& & & & \\
& & & & \\
Constant & 1.443 & -1.543 & 1.207 & -0.581 \\
& $(1.157)$ & $(-1.334)$ & $(1.826)$ & $(-0.721)$ \\
& & & & \\
Inf US & 0.319 & 0.947 & 0.337 & 0.855 \\
& $(1.297)$ & $(3.173)$ & $(2.566)$ & $(4.716)$ \\
& & & & \\
Inf $(t-1)$ & 0.502 & 0.293 & 0.411 & 0.266 \\
& $(3.861)$ & $(1.601)$ & $(3.325)$ & $(1.996)$ \\
& & & & \\
R2 & 0.405 & 0.708 & 0.447 & 0.754 \\
DW & 1.930 & 1.620 & 1.990 & 1.940 \\
Durbin's $\mathrm{n}$ & 0.480 & 3.192 & 0.083 & 0.216
\end{tabular}

(a) Yearly data. The first observation corresponds to the first year for which there is information. 


\section{II.2 Analysis with Quarterly Data: 1957-1983}

According to the relative version of PPP and to the simplest monetary theories of the international transmission of inflation, under a fixed nominal exchange rate system the rate of domestic inflation in a small open economy does not differ from "the" world rate of inflation (Swoboda, 1978). Under this setting, international price disturbances will be rapidly and fully transmitted into the domestic economy. Moreover, local central banks would have no room for engaging in monetary policy: a domestic excess supply (demand) for money will result in an equiproportional loss (gain) of international reserves, leaving the quantity of money and domestic prices unchanged in the domestic economy. If this simple model of the international transmission of inflation holds, we would expect that the time series of inflationary differentials between the domestic country and "the" world will be characterized by white noise.

Table 3 contains Augmented Dickey-Fuller (ADF) unit-root tests, and LjungBox statistics for white noise series. In every case inflation differentials were defined as follows:

$$
\operatorname{Dinf}_{t}=\pi_{t}-x_{t}^{\text {us }}
$$

where $x_{i}^{i}$ and $x_{s}^{\text {Us }}$ are quarterly inflation rates for the country in question and the U.S. As in the previous section, inflation is defined as the percentage change in the consumer price index. As can be seen from Table 3, in both cases the hypothesis that the inflationary differential has a unit root is rejected at conventional levels. The Ljung-Box Q statistics reported in the second column show, on the other hand, that the hypothesis that inflationary differentials is white noise cannot be rejected at the $1 \%$ level in the case of Guatemala. ${ }^{6}$ 


\title{
Table 3 \\ AUGMENTED DICKEY-FULLER AND LJUNG-BOX TESTS OF INFLATIONARY DIFFERENCES
}

Time Series: $\operatorname{Din} f(t)=\operatorname{In} f(i, t)-\operatorname{In} f(U S, t)$

\author{
Augmented \\ Dickey-Fuller (a) Ljung-Box Q (b)
}

\section{GUATEMALA}

$57.2 \cdot 78.4$

3.6

6.6

$57.2-82.2$

3.9

6.9

HONDURAS

$57.2 \cdot 78.4$

$-3.8$

16.2

$57.2 \cdot 82.2$

$-4.4$

18.6

(a) Computed with 4 lags. The critical value of the ADF statistic at the 5 percent level is -2.9.

(b) The critical values of the $Q$ statistlc with 8 degrees of freedom at 10 percent and 5 percent levels are 13.4 and 15.5 respectively. 
The analysis of the time series properties of Dinf reported in Table 3 contradicts that obtained from the simple partial adjustment model on annual data, and provides preliminary evidence suggesting that at least in the short run, variables other than "world" inflation affected domestic inflationary dynamics. From a policy perspective it is important to investigate what factors are behind the deviations from PPP reported above. A particularly interesting issue is whether inflation differentials responded to real or to monetary shocks.

In his celebrated 1964 article Balassa postulated that there are three fundamental real reasons for rejecting the relative version of PPP: (a) different rates of technological progress (or aggregate growth) across countries; ${ }^{7}$ (b) terms of trade shocks which affect the equilibrium real exchange rate; and (c) changes in commercial policy that alter taxes on international transactions.' In the case of Guatemala and Honduras, however, the latter explanation is rather implausible for 1930-83, since throughout most of this period there were only limited changes in commercial policy.

Another question refers to the possible role of monetary variables in explaining deviations from PPP. This is particularly important within the context of modem discussions on the role of fixed exchange rates as a "disciplinary" device and effective nominal anchor. It is also relevant to study the ability of the Central Bank to undertake independent monetary policy, and the possible role of real variables such as terms of trade shocks and growth differentials in explaining differences in inflation rates. ${ }^{9}$ In Section III we investigate the possible roles of both real and monetary variables in explaining inflation rate differential sin both countries between 1957 and 1983. 


\section{Monetary and Real Shocks, and Inflation Rate Differentials Under Fixed Nominal Exchange Rates}

\section{III.1 Fixed Exchange Rates and Credibility}

Most modern discussions on PPP and inflation rate differentials under fixed exchange rates have been couched within the context of credibility and time consistency literature. ${ }^{10}$ According to this approach governments that have the discretion to alter the nominal exchange rate will tend to abuse their power, introducing an inflationary bias into the economy (Calvo 1978, and Kydland and Prescott 1977). The reason for this is that under a set of plausible conditions, such as the existence of labor market rigidities that preclude the economy from reaching full employment, it will be optimal for the government to "surprise" the private sector through unexpected devaluations that, the government hopes, will reduce real wages and hike employment. ${ }^{11}$ In equilibrium the public will be aware of this incentive faced by the authorities, and will react to it by anticipating the devaluation surprises and hence rendering them ineffective. As a result the economy will reach a high inflation plateau. A key feature of the credibility literature is that under most circumstances policy commitment is welfare-superior to discretionary policy. If the government can credibly commit itself to low (or no) inflation, society will be better off: employment will be the same as in the discretionary policy case, but inflation will be lower. The problem, however, is that governments have a hard time making credible commitments. In the absence of effective constraints to tie the government's hands, any promise of low inflationary policy will not be credible and, thus, will be self-defeating.

The fundamental policy implication of this literature is that defining (and implementing) constraints that will make government pre-commitments credible, will result in an improvement in society's welfare. It has been argued that the adoption of 
a fixed exchange rate will constrain governments ability to surprise the private sector through unexpected devaluations. Promises of fiscal discipline will become credible and private sector actions will not elicit successive rounds of inflationary actions. ${ }^{12}$ In particular, it has been argued that fixed exchange rates provide a reputational constraint on government behavior. The authorities know that if they undertake overly expansive credit policy they will be forced to abandon the parity and devalue. As the recent crisis of the ERM has shown, exchange rate crises can indeed shatter the reputation of politicians. ${ }^{13}$

Devarajan and Rodrik (1992) and Kamin (1991), among others, have addressed the question of the desirability of fixed exchange rates from a more general perspective. ${ }^{14}$ For example, in Devarajan and Rodrik (1992), policy makers face a tradeoff regarding exchange rate policy: while exchange rate flexibility has an inflationary bias, it also allows the country to reduce output variability. This is accomplished by smoothing, via exchange rate adjustments, the consequences of terms of trade shocks on output. In this model it is not possible to rank a-priori fixed and flexible (or active) exchange rate regimes. For large terms of trade shocks it is more likely that flexible exchange rates will be superior. Likewise, the more vulnerable the real economy is to these terms of trade shocks, the more desirable will flexible arrangements become. On the other hand, the greater is the government's built-in inflationary bias, the greater will be its temptation to abuse devaluations, and the less desirable will a flexible arrangement become.

John Williamson (1991) has argued that a fixed exchange rate would be advisable as long as four conditions are met: (1) the country in question is "small" relative to the rest of the world; (2) the bulk of its intemational trade is undertaken with the country (or countries) with respect to which it plans to peg its currency; (3) 
the country wishes to have a rate of inflation similar to that of the country it is pegging its currency to; and (4) there are institutional arrangements that assure that the commitment to a fixed rate is credible. Williamson goes on to argue that, once these four conditions are met, the only remaining argument in favor of flexible exchange rates refers to terms of trade shocks.

Historically, Guatemala and Honduras have satisfied Williamson's first three conditions. Whether the fourth requirement - the existence of appropriate institutional arrangements - was fulfilled may be subject to some discussion. In both countries the Central Bank lacked formal independence, and the professional staffs were very small. Also, budgetary procedures for the public sector were primitive and lacked transparency. On the other hand, however, the most important institutional support for maintaining a fixed exchange rate was the very long history with this type of regime. As time passed, this remarkable history became a greater and greater reputational constraint, making the notion of devaluation unthinkable.

With respect to terms of trade, every Central American country - including Guatemala and Honduras - experienced increased volatility in the 1970s (see figure 2 for the Honduran case). This suggests that at some time, and due to changes in the nature of underlying shocks, an exchange rate regime that had been appropriate ceased to be so. Guatemala and Honduras, however, decided to maintain their fixed rates in spite of increasingly large external fluctuations. However, another Central American country, Costa Rica, opted for abandoning the fixed exchange rate in order to achieve a smoother external sector adjustment - even at the cost of higher inflation. Preliminary evidence discussed in Edwards (1994) suggests that, by allowing an early exchange rate realignment Costa Rica was able to achieve a significantly faster recovery in growth than its neighbors. 
FIGURE 2

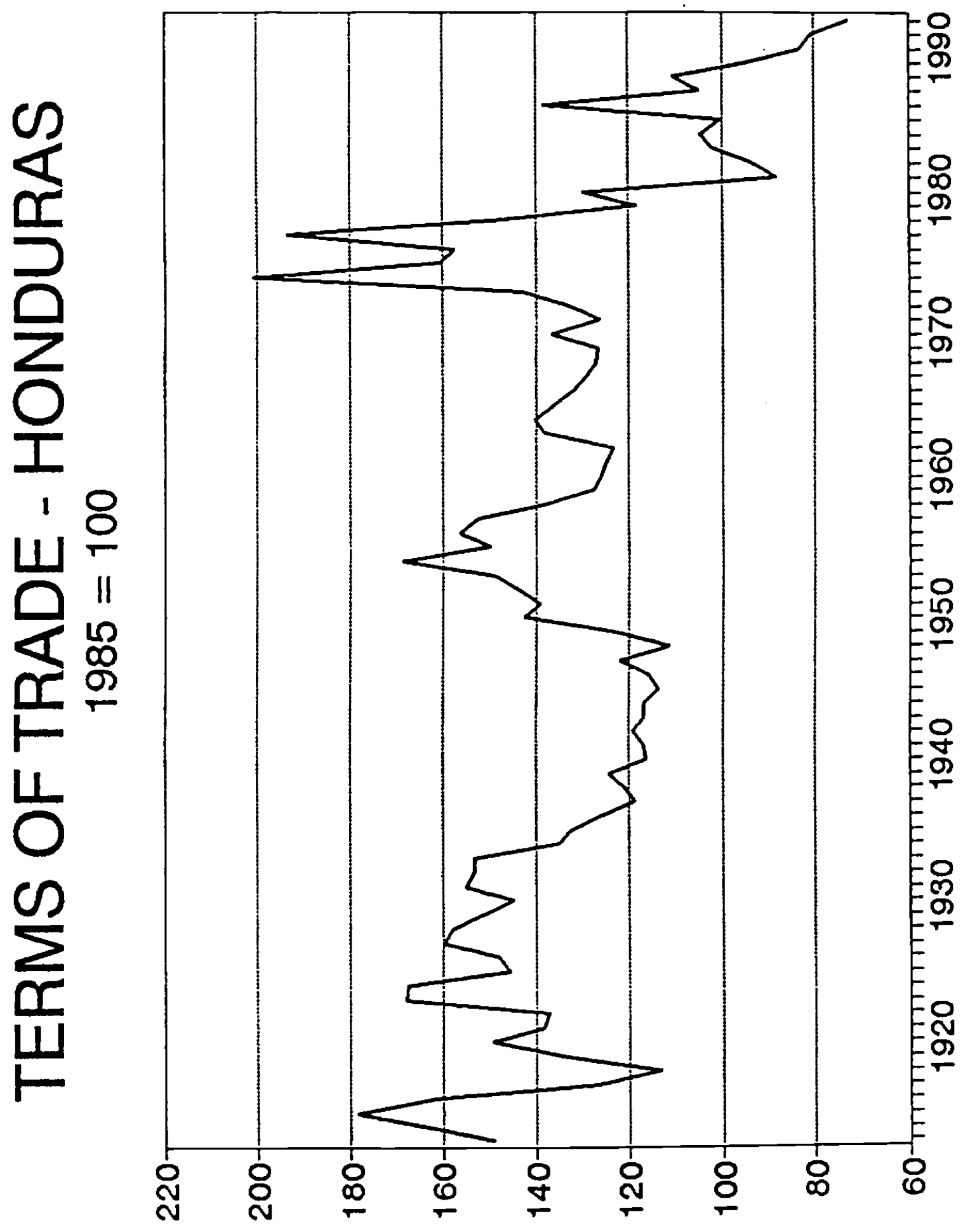




\section{III.2 Empirical Results}

Within the credibility framework discussed above it is important to understand whether, under a fixed nominal exchange rate regime, countries are able to undertake independent monetary policy. Stockman (1992) has analyzed the issue of monetary autonomy for a group of industrial countries during the Breton Woods era. He estimated a series of vector autoregressions for inflationary differentials, and tested whether the coefficients of money growth (as a group) were significantly different to zero. He found that for the majority of the countries the null hypothesis of zero money growth coefficients was rejected, and interpreted these results as evidence in favor of the hypothesis that industrial countries had some room to undertake independent monetary policy during the Bretton Woods era.

In a (small) open economy subject to exogenous shocks, Central Banks sometimes try to use monetary (or credit) policy in an attempt to counter the effects of terms of trade disturbances. Under these circumstances, domestic credit would be expanded when the terms of trade worsen, and contracted when the terms of trade improve. Naturally, under fixed exchange rates, the magnitude of credit expansion will be restricted by the availability of international reserves and the country's capacity to borrow internationally. Of course, a serious problem with this type of countercyclical domestic credit policy is that it requires that the authorities have a good notion of whether terms of trade shocks are temporary or permanent.

In order to deal with these issues we estimated equations of the following type using quarterly data for the four Latin countries in the sample:

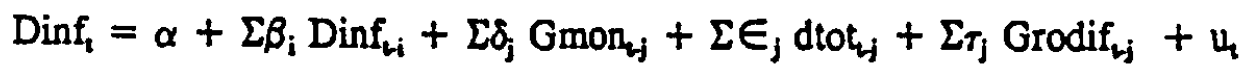


where, as before, Dinf refers to inflationary differentials; $\mathrm{Gmon}$ is the rate of growth of narrowly defined money for the country in question; dtot is the percentage change in the country's terms of trade; Grodif is the differential in the rate of growth of GDP between the country and the U.S., which along the lines of the empirical PPP literature, is used as a proxy for differences in technological progress across countries; $u$ is an error term; and $i=1, \ldots, 3$; and $j=0, \ldots 3 .^{15}$ If these countries enjoyed and practiced - monetary independence, we would expect that the coefficients of Gmon would be different from zero as a group. Terms of trade shocks and growth differentials are the real variables in this analysis. The role of external disturbances in the inflationary process is captured by the sum of the dtot coefficients. In order to look at this issue from different angles, we also estimated a series of equations of the type of (2), where we replaced Gmon for the rate of growth of domestic credit (Gcredit). ${ }^{16}$ Table 4 presents the likelihood ratio tests obtained from testing the hypotheses that: (a) the coefficients of Gmon - or those of Gcredit - were jointly zero; (b) the coefficients of dtot were jointly zero; and (c) that the coefficients of Grodif were jointly zero. As can be seen, the null hypothesis that the money growth coefficients are jointly equal to zero can be rejected at conventional levels in both countries. In the case of Gcredit the results are different; it is not possible to reject the null hypothesis in either country. Table 4 also shows that in only one regression Guatemala when Gcredit is the monetary variable - is possible to reject the hypothesis that the terms of trade coefficients are jointly zero. With respect to the growth differential terms, the null hypothesis was rejected in all regressions at conventional levels.

The results reported above are somewhat mixed. Although they suggest that central banks were able, at least in the short run, to engage in independent monetary 
Table 4

LIKELIHOOD RATIO TESTS ON THE SIGNIFICANCE OF MONETARY, TERMS OF TRADE AND GROWTH DIFFERENTIAL VARIABLES

$\begin{array}{lrr} & \text { GUATEMALA } & \text { HONDURAS } \\ \text { PERIOD } & 58.2-83.4 & 63.2-83.4 \\ & & \\ \text { Rate of Growth } & 9.144 & 13.739 \\ \text { of Money } & (0.058) & (0.008) \\ & & \\ \text { Rate of Growth } & & \\ \text { of Domestic Credit } & 1.382 & \\ & (0.847) & (0.141) \\ \text { Porcent Change } & & \\ \text { in Terms of Trade } & & \\ & & 5.551 \\ \text { a) With Money as } & & (0.235) \\ \text { Explanatory Variable } & 6.975 & 3.343 \\ \text { b) With Domestic Credit as } & (0.137) & (0.502) \\ \text { Explanatory Variable } & & \end{array}$

Growth Differentials

a) With Money as

Explanatory Variable

(0.602)

$(0.177)$

b) With Domestic Credit as

1.923

5.106

Explanatory Variable

(0.750)

$(0.277)$

(a) Numbers in parentheses are levels of significance. 
policy, the evidence in this regard is not overwhelming. In particular, it is somewhat surprising that the coefficients of Gcredit did not tum out to be significant as a group. As a way to further explore this issue we reestimated the Dinf equations, reducing the dimension of the vector auto regression. In the new estimates both terms of trade shocks and growth differentials were excluded from the analysis. Table 5 contains the likelihood ratio tests on the significance of $\mathrm{Gmon}$ and Gcredit for both countries. As can be seen in this case the null hypothesis that the monetary variables coefficients are jointly zero is rejected in both regressions. All in all, we interpret the evidence reported in this section as providing some evidence supporting the view that the monetary authorities in these countries were able to engage in independent monetary policy during the period. And yet, the fact that the fixed exchange rate regime was maintained throughout indicates quite clearly that this ability was not abused by the authorities. The next section deals with the issue of monetary policy and the abandonment of the exchange rate regime in some detail.

\section{Credit Policy and Exchange Rate Crises}

In the mid and late 1980s and early 1990s the long experience with fixed nominal exchange rates came to an end in both of our countries. Guatemala devalued in 1986, and Honduras abandoned its official parity in early 1990. These devaluations, however, were not easy to undertake. Even when the evidence overwhelmingly showed that the old regime was not sustainable any longer, the authorities in both countries desperately adhered to the fixed rate, and imposed severe exchange and capital controls in an effort to avoid the complete depletion of international reserves. As a result of this, significant black markets for foreign exchange were developed see figure 3 for the premium. In this section we analyze in some detail the behavior of 


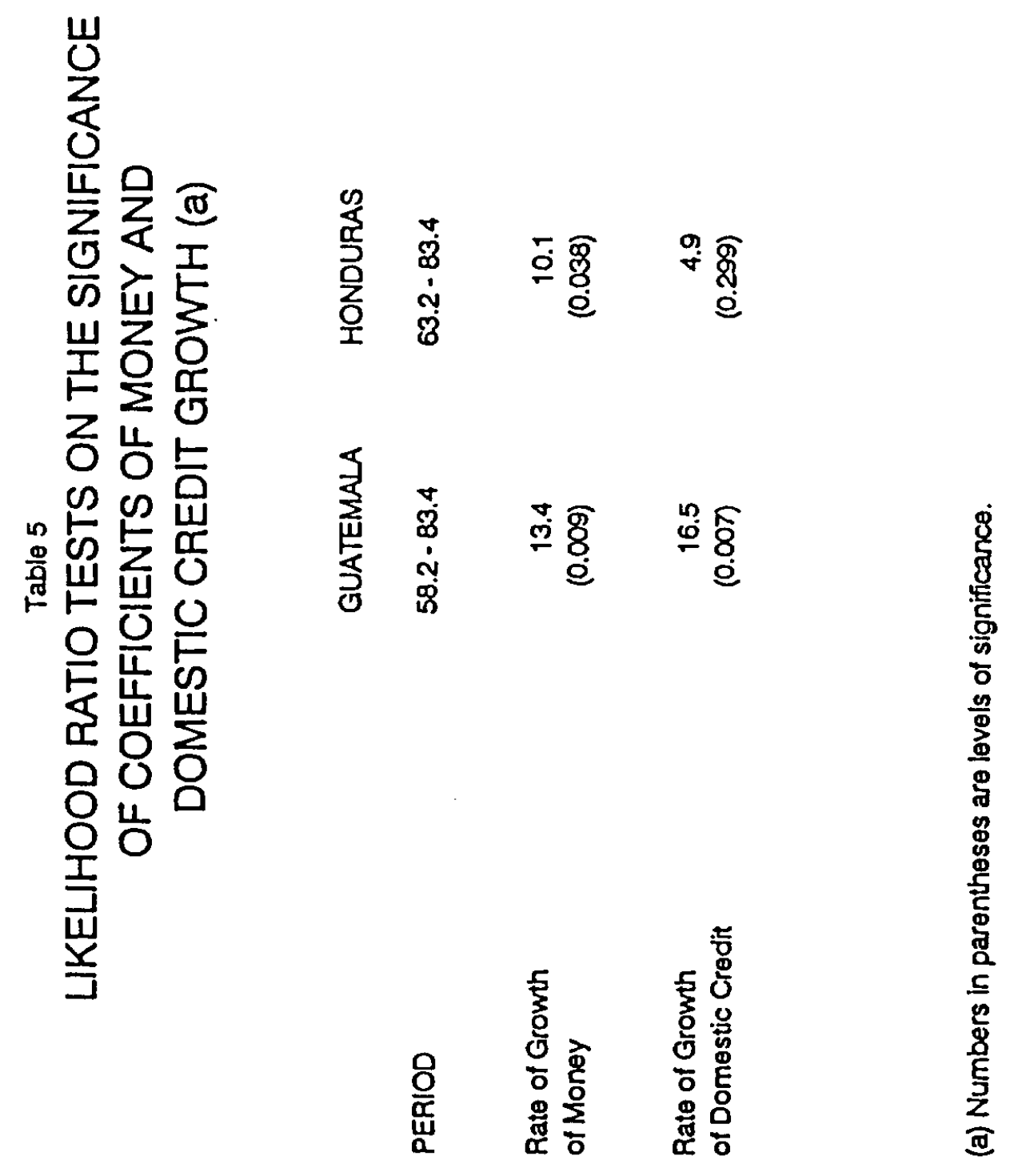


FIGURE 3

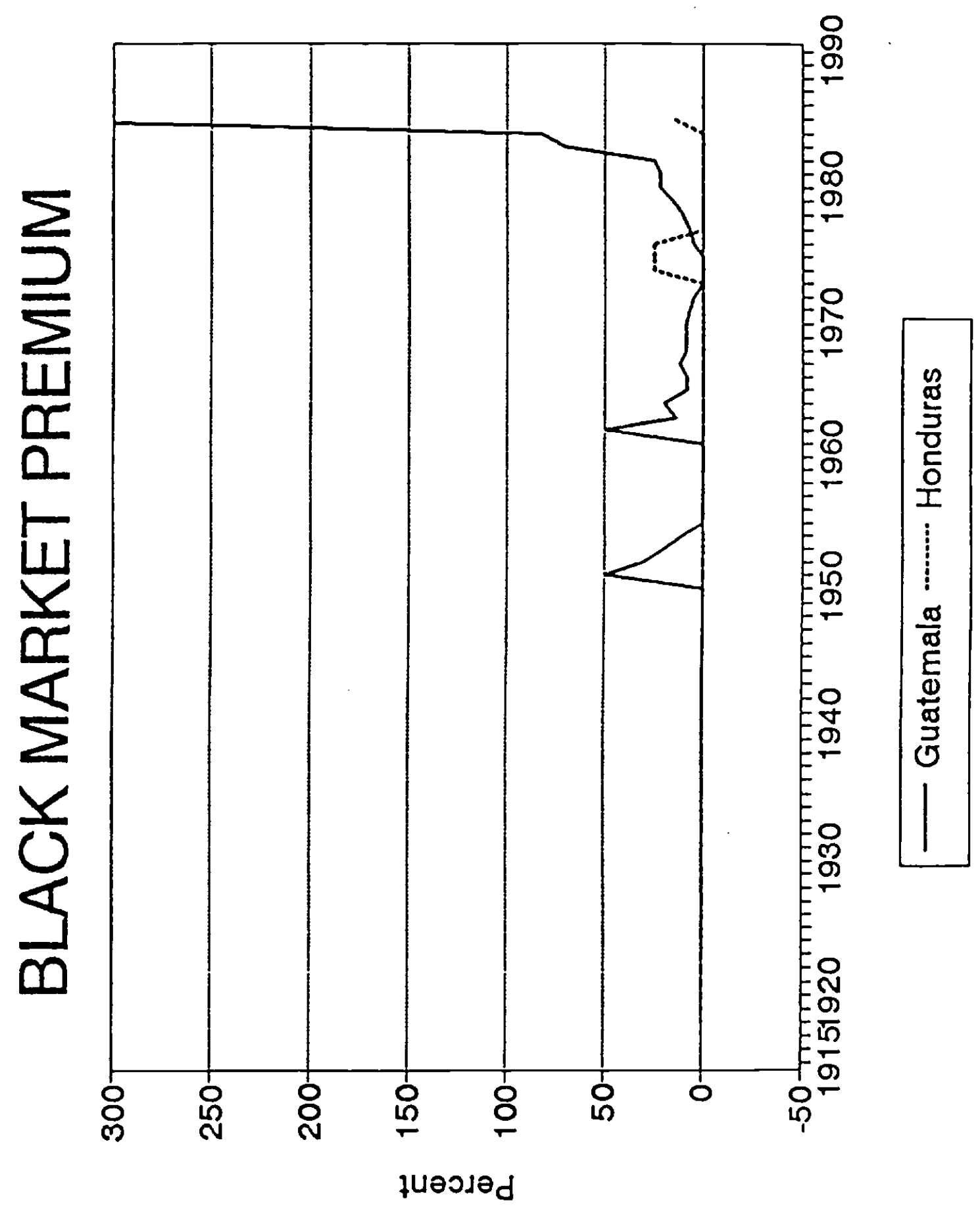


fiscal and monetary policy variables, and we investigate the circumstances that led to the abandonment of the fixed parities in the 1980s.

The fundamental feature of a fixed exchange rate system is that it imposes financial discipline on the Central Bank and other government agencies. The authorities are aware that if they systematically violate certain macroeconomic constraints the country will deplete its intemational reserves to a minimum level, and will be forced to give up the parity. Consequently, a fixed exchange rate imposes upper bounds to domestic credit creation and fiscal imbalances. These constraints, however, operate in the medium to long runs, and do not have to be observed at every moment. It is, in fact, perfectly possible that in a particular period credit creation exceeds this "threshold". However, when this happens, the authorities will rapidly try to change directions, bringing macro policy back to a consistent course. ${ }^{17}$

If the country can increase its foreign indebtedness, the macro constraints can be side stepped for a longer period of time. This, however, cannot be a permanent solution. As the Latin countries found out the hard way in the early 1980 s, at some point the international community will stop providing funds, and a crisis will erupt.

Fixed rates impose two basic financial constraints: first, domestic credit cannot grow, on average, at a rate faster than that of the demand for money. This, in turn, is determined by "world" inflation, real income growth and the income elasticity of the demand for money. ${ }^{13}$ Second, the fiscal deficit (as a proportion of GDP) financed by money creation cannot exceed a certain bound determined by the increase in the demand for money and the degree of monetization of the economy. ${ }^{19}$

Figures 4 and 5 display estimated annual upper bounds or thresholds as well as actual rates of domestic credit creation and the fiscal deficit for our two countries. ${ }^{20}$ In these figures the solid lines represent the actually observed series, while the broken 
GUATEMALA

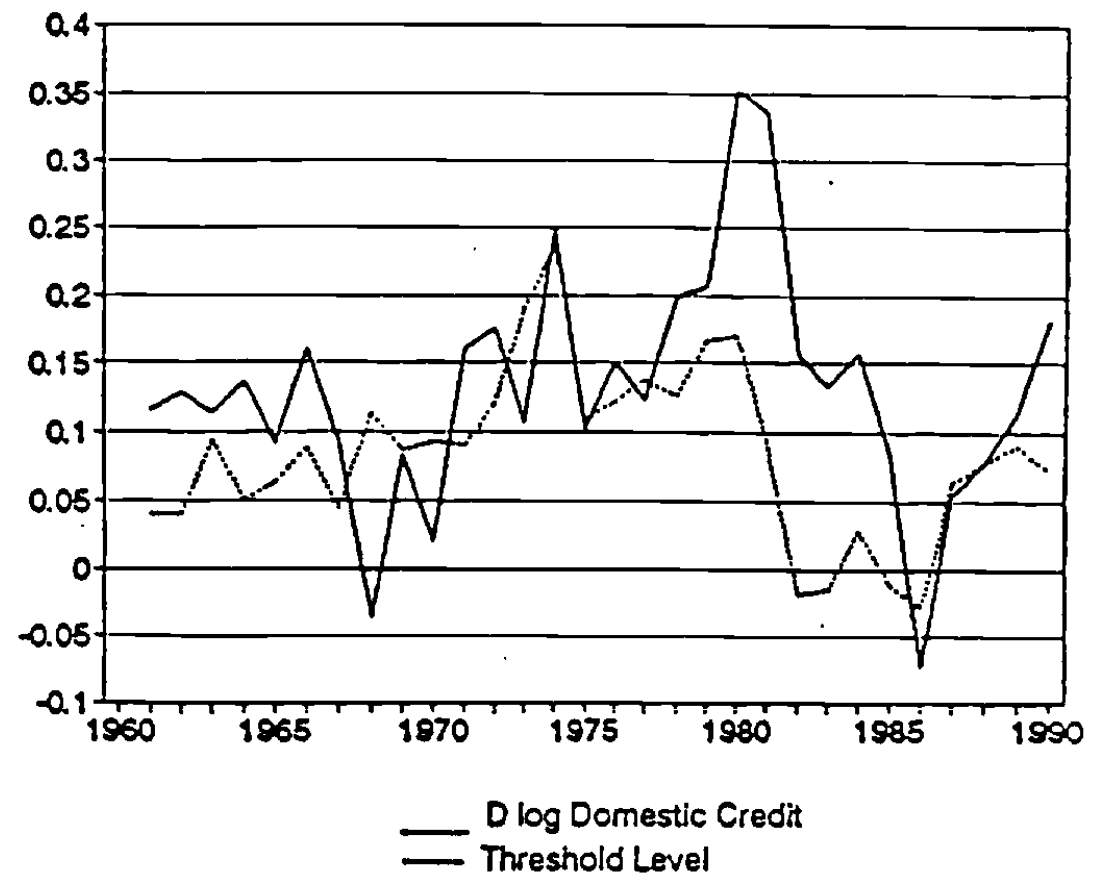

GUATEMALA

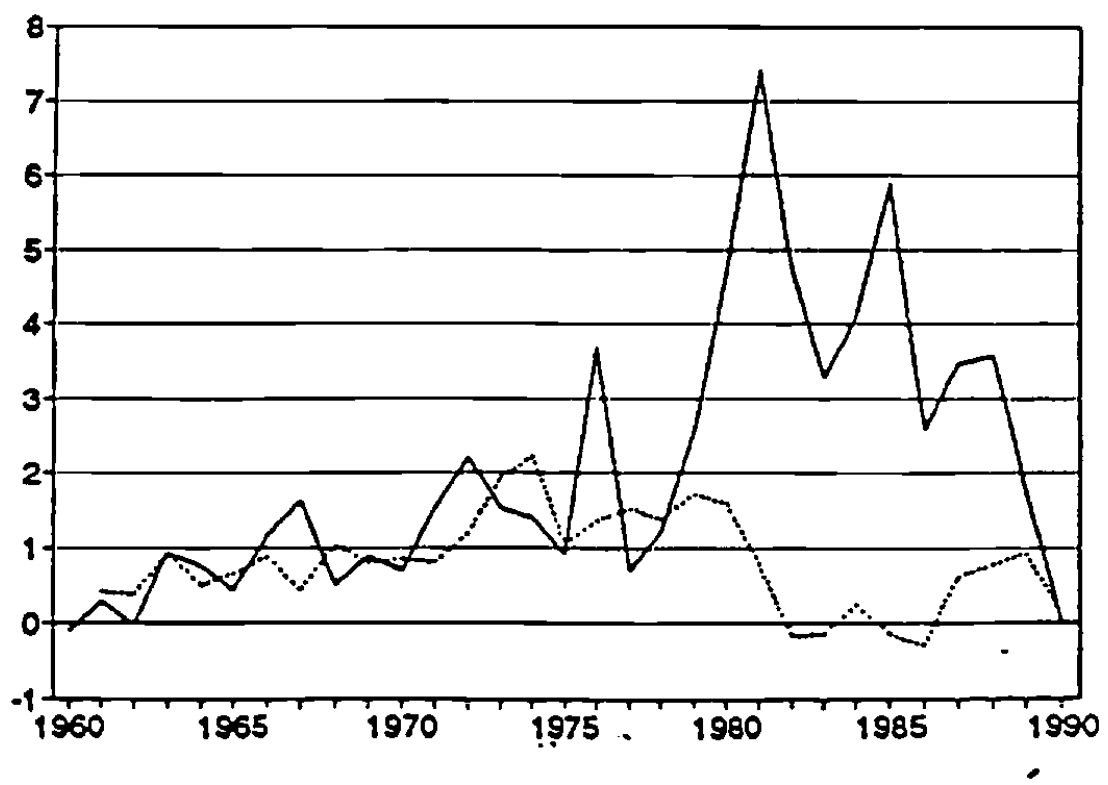

Fiscal Deficit / GDP

- Threshold Level 


\section{HONDURAS}

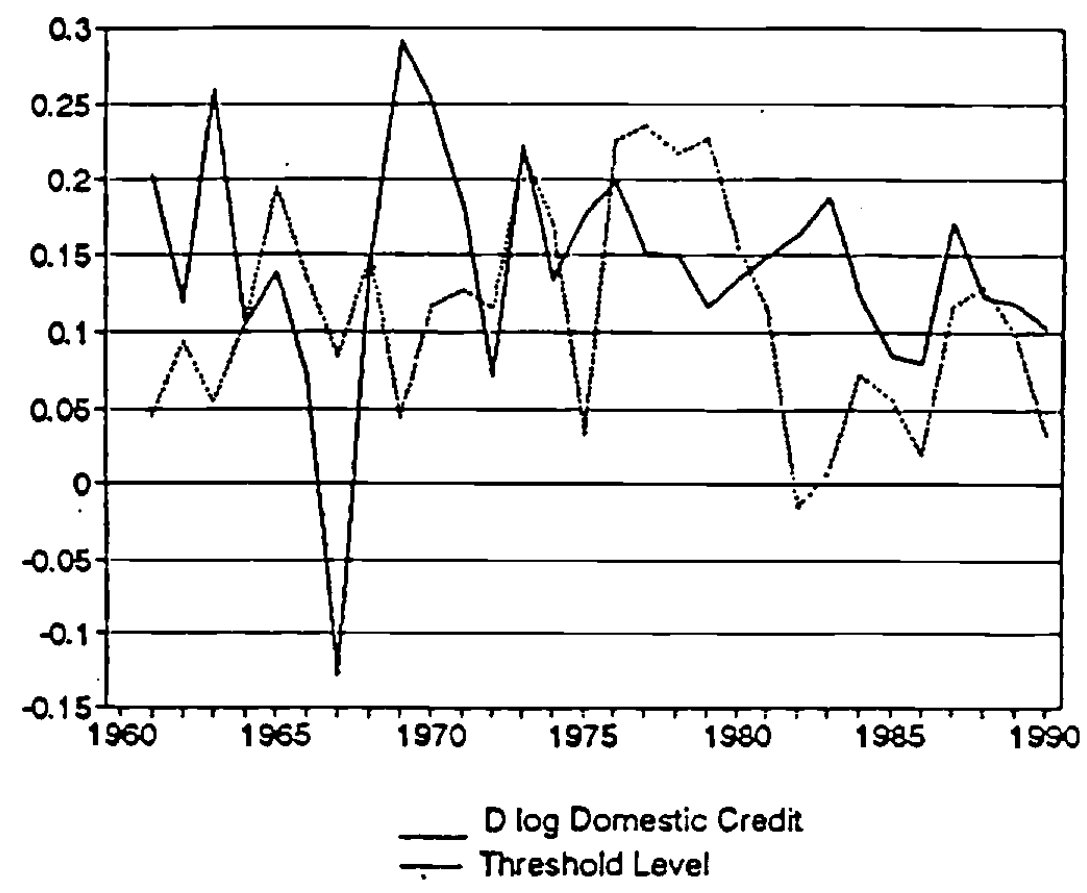

HONDURAS

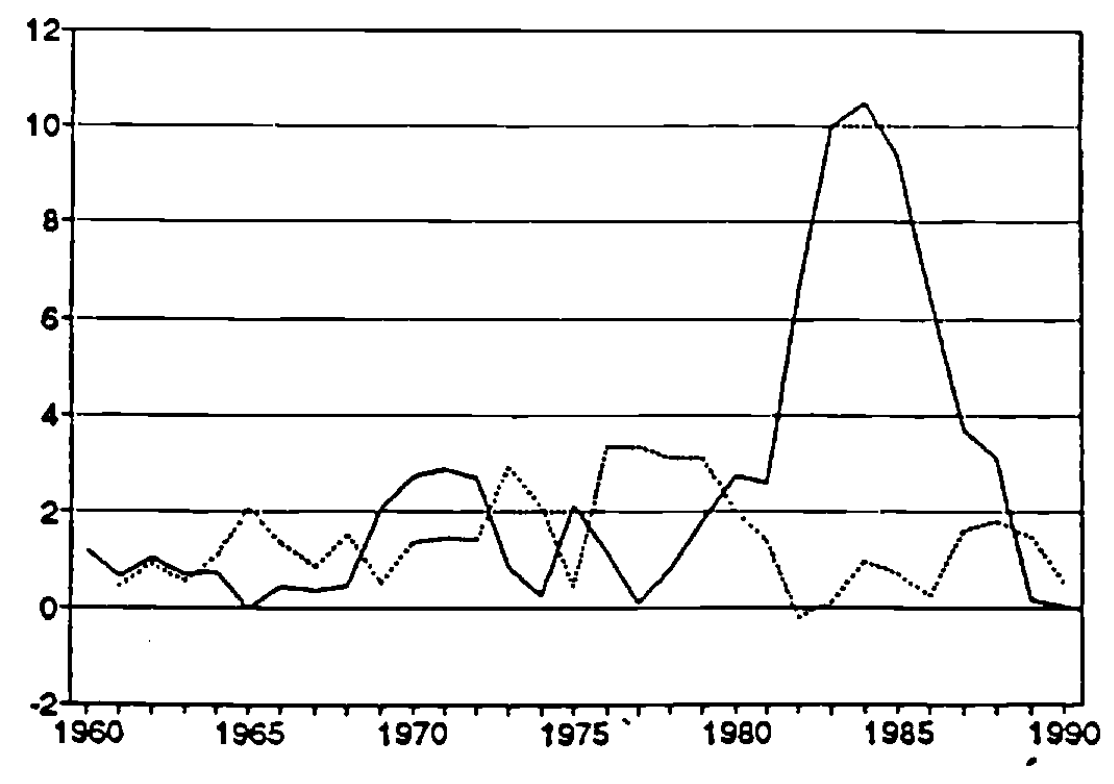

Fiscal Deficit / GDP

- Threshold Level 
lines are the "upper bounds" imposed by the fixed nominal exchange rates regime. These figures, then, capture the periods during which the bounds were exceeded. During the early years (up to the mid to 1970 s or early 1980 s, depending on the country) the bounds seemed to have been very effective. Every time the actual rate of credit creation, or the deficit ratio, exceeded their respective thresholds the authorities rapidly implemented corrective policies bringing the policy variable below the bound. These data suggest that during these years Guatemala and Honduras followed the "rules of the game", and acted as if the nominal exchange rate regime imposed a financial constraints. In the late 1970 s and early 1980 s, however, this behavior breaks down; as the figures show in both countries the two policy indicators exceed the estimated thresholds without returning, in the short or medium runs, to a level consistent with fixed exchange rates.

In order to further investigate the behavior of credit policy in the period preceding the devaluation crisis, we estimated vector autoregressions for domestic credit growth for the core period under fixed exchange rates, 1957-75. ${ }^{21}$ We then compared forecasted values obtained from these equations with actual credit growth. As Table 6 shows, in both Guatemala and Honduras the forecasted rate of growth of domestic credit was below the actual growth between 1977 and 1981. This suggests that if the authorities had maintained the historical policy behavior in the period preceding the debt crisis, the rate of credit expansion would have been significantly below what was observed. This departure from the policies that respected the nominal anchor constraint created the increasingly large inflation rate differential reported above, and eventually led to the collapse of the fixed rate regime. 


\section{Table 6 \\ ACTUAL AND ESTIMATED RATES OF GROWTH \\ OF DOMESTIC CREDIT (a)}

PERIOD ACTUAL GROWTH OF
DOMESTIC CREDIT

GUATEMALA

$77.1-81.1$

5.76

(5.23)

78.1-81.1

6.78

(4.04)

$79.1 \cdot 81.1$

7.49

(3.46)
FORECASTED GROWTH

OF DOMESTIC CREDIT

HONDURAS

77.1-81.1

3.72

3.04

(3.13)

(3.12)

78.1-81.1

3.62

3.03

(3.10)

(2.90)

79.1-81.1

(a) Numbers in parentheses are standard errors. 


\section{Concluding Remarks}

The purpose of this paper has been to investigate some aspects of Latin America's experience with fixed exchange rates at the light of Bela Balassa's contributions to the purchasing power parity theory. The analysis has dealt with both long term characteristics of this system in Latin America. We evaluated the long-term experiences of two Latin American nations with fixed exchange rates. The evidence analyzed suggests that the relative version of PPP did not hold in Guatemala and Honduras. However, in spite of the that these countries had the ability to conduct independent monetary policy, the existence of a long tradition of exchange rate stability provided some constraints on Central Bank behavior. This evidence, however, also indicates that these constraints were limited, and would not survive the combination of populist political pressures and severely negative terms of trade shocks in the late 1970s and early 1980s. In fact, our analysis suggests that in the mid 1970s domestic credit and fiscal policies undertook a significant change, and were not any longer constrained by the existence of a fixed nominal exchange rate. 
Appendix - Central American Experiences with Fixed Exchange Rates: A Brief Bistory

\section{GUATEMALA}

Early in 1919 Princeton professor and economic advisor Edwin Kemmerer was hired by the Guatemalan government to prepare a proposal for monetary reform. The fall of dictator Estrada Cabrera a year later prevented Kemmerer's Gold Standard proposal to be adopted. In September 1923 the Caja Reguladora was established to stabilize exchange rate with funds earmarked from taxes on coffee and stop the fall in the value of the peso. Kemmerer was invited again in 1924, and a currency reform initiated. The Quetzal was established as the new monetary unit, to be issued at par with the dollar.

The first Central Bank of Guatemala was founded in 1925 with very little foreign technical assistance. It was a semi-public institution, whose department of currency issue only discounted short run trade bills. Besides, this bank also operated as a commercial institution. It was managed by a Junta Directiva composed by 9 members, 2 chosen by the government and 7 by the stockholders.

In 1926 the Guatemalan authorities were finally persuaded by Kemmerer's early proposal, and the country embraced the Gold Standard. The Caja Reguladora was reorganized as the Banco Central de Guatemala, with monopoly of note issue. The exchange rate was fixed at 60 pesos per Quetzal or dollar (the peso had been at par with the dollar in 1870.) The new currency was linked at par with the U.S. dollar, starting a tradition of more than half a century of fixed parities. It was a fully transferable paper currency, covered by 50 percent in gold and 30 percent in dollar assets. In February 1934 the Quetzal was devalued along with the dollar, and the official gold price increased to 35 Quetzales per ounce. 
In December 1945 the Banco de Guatemala replaced the old central bank. Several economists from the Federal Reserve System (Robert Triffin and Henry Wallich among others) were part of the reorganization task force. The new Junta Monetaria was composed by six members, four representatives from the public sector, one from the University of San Carlos de Guatemala and one from the private financial sector, and was in charge of designing and implementing monetary, credit and exchange rate policies of Guatemala. In December 1946 Guatemala joined the IMF and the World Bank, as part of the so-called "dollar area." In March 1956 Guatemala became a member of the International Finance Corporation.

Col. Arbenz Guzman came to power on March 1951, and then several collectivist experiments were implemented, as for instance the nationalization of real estate holdings of foreign companies. As a result, a black market for U.S. banknotes emerged, and the premium reached 25 percent. In 1954, after a coup d'etat led by Col. Castillo Armas, black markets finally disappear.

By 1962 a new era of political unrest had begun, and the black market exchange rate peaked at 1.5 per dollar. A multiple exchange rate system was established on October 1962, and exchange controls were enacted for the first time in Guatemalan history. After the implementation of an economic austerity plan, the multiple exchange rate system was abolished in May 1963, and the parity was once again unified at one Quetzal per dollar.

Exchange controls were slowly enacted starting in 1980, as a consequence of the state of belligerance in Central America. The outburst of civil war in 1981 led to the breakdown of the CACM and growing protectionism. Besides, an excessively expansionary fiscal policy gave rise to a process of real exchange rate overvaluation and loss of international reserves. During the first half of the 1980s, the black market 
premium increased constantly, peaking at more than 250 percent in 1985. A three-tier exchange rate system was created in November 1984. The official rate of one Quetzal per dollar was maintained for most export receipts, proceeds from foreign borrowing, and for the service of the external public debt. An auction market rate ruled certain import payments, and a fluctuating bank rate was effective for all other dealings. There were also mixed export rate for sugar, cotton and meat from outside the Central American Common Market (80 percent official and 20 percent fluctuating.) A partial devaluation was undertaken in February 1985, by shifting commodities to the fluctuating exchange rate. A tax of 3.5 percent on foreign exchange operations was established in July 1985, and the mixed export rate was finaly devalued in October of the same year. The exchange rate system was simplified in June 1986. The official rate was set at one Quetzal per dollar for previously contracted foreign debt; the fluctuating rate became the interbank rate at 2.9 for remittances and tourism, and the auction market rate was replaced with the regulated market rate at 2.5 for imports and exports, while all foreign exchange taxes were eliminated. Finally, the exchange market was unified in June 1988.

\section{HONDURAS}

In the early 1900 Honduras split in two parts for currency purposes: the dollar was means of payments and unit of account in the northern coast (banana production areas) while silver currency ruled in the rest of the country. In May 1918 the government authorized a private commercial bank (Banco Atlantida) to redeem notes in dollars. The US currency was declared legal tender, and the official exchange rate fixed at two pesos per dollar. The new currency was linked to gold at the rate of 
0.836 grams per unit. In 1919 the Banco Atlantida was obliged to keep reserves in gold or dollars.

In 1921, Arthur Young, a US currency expert, presented a plan for monetary reform based on the Gold Standard to the Congress, which was not acted on. Gold and silver circulated side by side during the 1920s, until the Lempira was introduced as new currency in 1931. Its parity was 2 to 1 relative to the U.S. dollar. The Lempira was devalued along with the dollar in February 1934, while the gold content of the Lempira was reduced to 0.444 grams, marking the end of the Gold Standard in Honduras.

Prior to February 1950, Honduras had only two banks - Banco de Honduras and Banco Atlantida, both private. In that year, the Banco Central de Honduras was established with the technical support of the MMF. As in the case of Guatemala, a Junta Monetaria, with representatives from the government, official development agencies, commercial banks, and primary productive sectors, was responsible for the monetary policy of the country. On September 1955 the new banking law was approved, setting the regulatory framework for the establishment of financial institutions.

The Lempira maintained its link with the dollar after August 1971, which entailed a de facto devaluation. The gold content of Lempira was reduced 7.89 percent the following December, and again on February 1973 by another 10 percent.

In the beginning of the 1980 s overly expansive fiscal policies gave rise to a large disequilibrium in the external sector, because of the incipient overvaluation trend in the real exchange rate. With the intensifications of social tensions there was an increase in capital flight, until 1980 when capital controls were imposed. Moreover, starting in 1982 a large series of trade barriers were established as a reaction of the 
lack of foreign funds to finance the external sector deficit. A parallel market rate for commercial transactions with Central American countries was established in March 1985, followed by a program of subsidies to non-traditional exports in December 1987, which in practice meant a highly distortive system of multiple exchange rates.

Meanwhile, the parallel market premium increased from 20 percent in 1986 to 80 percent in 1989, signalling a growing imbalance in the external sector. Finally, a period of more than 70 years of fixed parities came to an end in March 1990, when the Lempira was devalued. 
References

Aghevli, B., M. Khan and P. Montiel; "Exchange Rate Policy in Developing Countries: Some Analytical Issues", DMF Occasional Paper No. 78, 1991.

Balassa, B.; "Recent Developments in the Competitiveness of American Industry and Prospects for the Future", in Factors Affecting the U.S. Balance of Payments, Washington, D.C., U.S. Congress Joint Economic Committee, 1962.

; "The Purchasing Power Parity Doctrine: A Reappraisal", Ioumal of Political Econemy, Vol. 72, 1964. 1967.

; Studies in Trade Liberalization, Baltimore, Johns Hopkins University Press, ; Development Strategies in Semi-Industrial Economies, Baltimore, World Bank / Johns Hopkins University Press, 1982.

-_ ; New Directions in the World Economy, London, Macmillan, 1989.

Bruno, M.; "High Inflation and the Nominal Anchors of an Open Economy", Princeton Essays in International Finance No. 183, 1991.

Calvo, G.; "On the Time Consistency of Optimal Policy in a Monetary Economy", Econemetrica, Vol. 46, November 1978.

Cassel, G.; "The Present Situation of the Foreign Exchanges", Economic Joumal, Vol. 26, March 1916.

Clague, C.; "Why are Prices so Low in America?", The World Economy, Vol. 16, No. 5, September 1993.

Corden, W.M.; "Monetary Integration", Princeton Essays in International Finance No. 93, April 1972.

- ; "Exchange Rate Policy in Developing Countries", in J. de Melo and A.

Sapir (eds.), Trade Theory and Economic Reform, Oxford, Blackwell, 1991.

Devarajan, S. and D. Rodrik; "Do the Benefits of Fixed Exchange Rates Outweight Their Costs? The CFA Zone in Africa", in I. Goldin and A. Winters (eds.), Open

Economies: Structural Adjustment and Agriculture, Cambridge, Cambridge University Press, 1992.

Edwards, S.; Exchange Rate Misalignment in Developing Countries, Baltimore, Johns Hopkins University Press, 1988.

- ; Real Exchange Rates. Devaluation and Adjustment, Cambridge, MIT Press, 1989. 
_._._._. "Exchange Rates as Nominal Anchors", Weltwirtschaftliches Archiy, Vol. 129, No. 1, 1993.

; "Exchange Rates, Inflation and Disinflation: Latin American Experiences", in S. Edwards (ed.), Capital Controls. Exchange Rates and Monetary Policy in the World Economy, Cambridge, Cambridge University Press, forthcoming 1994.

Flood, R. and P. Isard; "Monetary Policy Straegies", Cambridge, NBER Working Paper No. 2770, 1988.

Frenkel, J.; "A Monetary Approach to the Exchange Rate: Doctrinal Aspects and Empirical Evidence", in J. Frenkel and H. Johnson (eds.), op. cit., 1978.

- and H. Johnson (eds.); The Economics of Exchange Rates, Reading, Addison-Wesley, 1978.

Houthakker, H.; "Exchange Rate Adjustment", in Eactors Affecting the U.S. Balance of Payments, Washington, D.C., U.S. Congress Joint Economic Committee, 1962.

Kamin, S.; "Exchange Rate Rules in Support of Disinflation Programs in Developing Countries", Washington, D.C., Board of Governors of the Federal Reserve System, mimeo, June 1991.

Kydland, F. and E. Prescott; "Rules Rather Than Discretion: The Inconsistency of Optimal Plans", Loumal of Political Economy, Vol. 85, August 1977.

Marston, R.; "Real Exchange Rates and Productivity Growth in the United States and Japan", in S. Anndt and J. D. Richardson (eds.), Real-Financial Linkages Among Open Economies, Cambridge, MTT Press, 1987.

McKinnon, R.; "Optimum Currency Areas", American Economic Review, Vol. 53, September 1963.

Mundell, R.; "A Theory of Optimum Currency Areas", American Economic Review, Vol. 51, September 1961.

Obstfeld, M.; "Can We Sterilize? Theory and Evidence", American Economic Review, Vol. 72, May 1992.

Persson, T. and G. Tabellini; Macroeconomic Policy, Credibility and Politics, New York, Harwood, 1990.

Stockman, A.; "International Transmission Under Bretton Woods", Cambridge, NBER Working Paper No. 4127, July 1992.

Svensson, L.; "Fixed Exchange Rates as a Means to Price Stability: What Have We Learned?", Cambridge, NBER Working Paper No. 4504, October 1993. 
Swoboda, A.; "Gold, Dollars, Euro-Dollars and the World Money Stock Under Fixed Exchange Rates", American Economic Review, Vol. 68, June 1978.

Viner, J.; Studies in the Theory of International Trade, New York, Harper, 1937.

Williamson, J.; "Advise on the Choice of an Exchange Rate Policy", in E. M. Claasen (ed.), Exchange Rate Policies in Developing and Post-Socialist Countries, San

Francisco, International Center for Economic Growth, 1991. 
</ref_section> 
Endnotes

1. Viner (1937) gives a flavor of the debate.

2. Strictly speaking Balassa's theorem also requires that the share of tradables in the price index is the same across countries.

3. See, in particular, Balassa $(1962,1964)$.

4. We have been unable to find a complete time series of Honduran and Guatemalan prices for the period prior to 1990.

5. A number of authors have (correctly) argued that, in general, world inflation should be measured using a basket of foreign inflation. In the case of Central America, however, the overwhelming majority of trade is with the U.S. This justifies using U.S. inflation as a proxy. Notice that the estimation of (1) using conventional techniques assumes that inflation is stationary. This is discussed in greater detail in the section that follows.

6. Edwards (1994) also looks at the experiences of El Salvador and the Dominican Republic.

7. For a detailed discussion of alternative tests of PPP see Officer (1986). Svensson (1993), for example, refers to the Balassa effect as dealing with growth differentials.

8. All of these are what have become to be known as real exchange rate fundamentals. See Edwards (1989).

9.This discussion is somewhat related to traditional debates on sterilization and the "offset" coefficient. See Obstfeld (1982).

10.The new impetus for fixed rates has strongly emerged in the International Monetary Fund. See Aghevli et al. (1991).

11.This assumes that wages are set before the government implements the exchange rate policy, but after it has been announced.

12. Aghevli et al. (1991).

13. In spite of its elegant appeal, this view has, in its simplest incarnation, some serious limitations. First, in these simple settings exchange rate policy has a very restricted role. In fact, in most of these models its only effect is to alter the domestic rate of inflation and, through it, the government perceives it as altering real wages. However, in most modern exchange rate models, nominal devaluations can also help accommodate shocks to real exchange rate fundamentals - including shocks to the terms of trade helping to avoid RER misalignment. Second, in economies with stochastic shocks, contingent exchange rate rules can, at least in principle, be superior to fixed rates (Flood and Isard 1988). Third, it is not clear why a country 
that can credibly commit itself to unilaterally fixing the exchange rate, cannot commit itself to maintaining a fixed stock of domestic money, or to follow a specific monetary rule.

14. Mundell (1961) and McKinnon (1963) had earlier addressed the same problem in the context of optimal currency areas. See also Corden (1972).

15.The data were obtained from the International Financial Statistics. The monetary data were "centered" in order to make them compatible with the inflation figures, which refer to period averages.

16. Since Gmon may not be completely exogenous, using Gcredit helps deal the endogeneity issue. The problem of potential exogeneity was also tackled by computing variance decompositions for a series of estimated VARs. In all cases, and under all possible orderings of the variables, the results provide strong indications that Gmon was, at least up to 6 quarters, exogenous.

17. That is, under fixed exchange rate constraints it is assumed that macro authorities follow the "rules of the game".

18. This assumes several things: first, the initial ratio of domestic credit to money is equal to the desired ratio. This is equivalent to saying that initially the Central Bank holds the desired ratio of reserves. Second, it assumes that the opportunity cost of holding money does not vary excessively, and can be ignored. Third, it assumes that the external debt/GDP ratio is in equilibrium.

19.Formally this constraint is derived from the public finance approach to inflation. The deficit to GDP ratio (d) cannot exceed the rate of growth of money demand ( $\mathrm{dM} / \mathrm{M})$ times the initial ratio of money to GDP.

20.In order to compute the upper bounds it was necessary to first obtain data on the long run income elasticity of the demand for money. We estimated demand for money equations for each country independently, using annual data for 1950-80. In the case of Guatemala the estimated value was 1.1; for Honduras was 1.8.

21. In addition to lagged values of domestic credit growth, we used U.S. inflation and real GDP growth in the country in question. Three lags of each variable were included. 